\title{
STRATEGI KOMUNIKASI PSIKOLOG DALAM PENANGANAN KORBAN PENYALAHGUNAAN NARKOBA DI RUMAH SAKIT JIWA PROVINSI BALI
}

\author{
Anak Agung Rai Tirtawati \\ Program Studi Ilmu Komunikasi Fakultas Ilmu Komunikasi Universitas Dwijendra \\ Made Yogi Artha Sudarta \\ Program Studi Ilmu Komunikasi Fakultas Ilmu Komunikasi Universitas Dwijendra \\ Email : Madekix@gmail.com
}

\begin{abstract}
ABSTRAK
Pergaulan di Indonesia sekarang banyak mulai mengikuti trend gaya barat. Dimana banyak kita temui masyarakat Indonesia yang memakai pakaian seksi, kebut-kebutan di jalan, memakai narkoba, mabuk- mabukan. Dalam penelitian yang berjudul Strategi Komunikasi Psikolog Dalam penanganan Korban Penyalahgunaan Narkoba di Rumah Sakit Jiwa Provinsi Bali, bertujuan untuk mengetahui strategi komunikasi apa yang digunakan selama proses rehabilitasi korban penyalahgunaan narkoba di rumah sakit jiwa provinsi bali dan hambatan komunikasi apakah yang dihadapi psikolog dalam penanganan korban penyalahgunaan narkoba. Peneliti menggunakan pendekatan kulitatif, dalam hal ini peneliti menggunakan 2 orang psikolog untuk dijadikan informan. Teknik pengumpulan data yang dilakukan yaitu wawancara, observasi, dokumen. Analisis data yang dilakukan peneliti adalah teknik analisis deskripstiif. Strategi komunikasi yang digunakan psikolog dalam penanganan korban penyalahgunaan narkoba di Rumah Sakit Jiwa Provinsi Bali adalah Sebelum melakukan rehabilitasi pasien korban penyalahgunaan narkoba. Psikolog terlebih dahulu melakukan assement kepada si korban, untuk mengetahui riwayat hidup korban. Mulai cara berkomunikasi,lingkungan,keluarga si korban. Setelah mendapaatkan data si korban, barulah nantinya akan diambil tindakan oleh psikolog. Selama proses rehabilitasi psikolog selalu memberikan pesanpesan komunikasi yang ingin disampaikaan saat mereka memasuki masa rehabilitasi. Berupa memberikan edukasi bagaimana caranya untuk berubah serta berhenti menggunakan narkoba. Didalam proses rehabilatasi psikolog memposisikan diri sebagai teman atau orang yang bisa mereka percayai dengan memberikan empati kepada mereka untuk mencari tahu akar permasalahan dari penyebab mengapa mereka menggunakan narkoba dan mencari tahu bagaimana cara dia untuk mengatasi masalahnya. Saat melakukan proses rehabilitasi ini psikolog juga memiliki trik atau terapi khusus melalui metode holistic ( menyeluruh ) untk mementukan aspek pribadi,lingkungan, serta komunikasi si korban. Selain itu juga psikolog juga memiliki metode 5B yaitu Berobat teratur selalu melakukan kontrol dan cek urine, Berkomunikasi selalu menyampaikan masalaah yang mereka miiliki, Beraktifitas melakukan kegiatan-kegiatan yang yang positif, Berekreasi selalu berolahraga, dan Berdoa. Cara psikolog mengetahui potensi diri dari diri mereka sendiri. Dengan cara psikotest atau tes minat bakat dan melakukan pendataan tentang riwayat hidup si korban.dengan keluarga. Untuk membangun kepercayaan diri korban penyalah gunaan narkoba agar mau diterima kembali dalam lingkungan masyarakat. Dengan caramelihat dan memberitahukan potensi diri yang dia miliki serta sadari akan kelebihannya. Hambatan-hambatan komunikasi yang dialami psikolog dalam penanganan korban penyaahgunaan narkoba adalah kesulitann dalam bekeluarga, teman, HP atau teknologi, Uang.
\end{abstract}

Kata kunci : Strategi Komunikasi, Psikolog, Korban Penyalahgunaan Narkoba 


\begin{abstract}
ABSTRAC
Relationships in Indonesia are now starting to follow the western style trend. Where many of us meet Indonesian people who wear sexy clothes, speeding on the road, using drugs, getting drunk. This is due to environmental factors in society and families that are not harmonious. One of the most interesting things for us is the number of drug users in Indonesia due to the magnitude of the current association. According to data from the National Narcotics Agency during 2015 the National Narcotics Agency revealed 102 cases of Narcotics and TPPU which are national and international network syndicates, where 82 cases. The cases that have been revealed involve 202 suspects consisting of 174 Indonesian citizens and 28 foreigners. Where there are 55 people convicted in the Narcotics case who received the death sentence, in which 14 people sentenced to death in Narcotics cases are waiting for the execution of the death penalty. In a study entitled Psychological Communication Strategy in the handling of Drug Abuse Victims in Bali Mental Hospital, aims to find out what communication strategies are used during the rehabilitation process of drug abuse victims in Bali provincial psychiatric hospitals and what communication barriers psychologists face in handling abuse victims drugs. The researcher used a skinative approach, in this case the researcher used 2 psychologists to be used as informants. Data collection techniques carried out are interviews, observation, documents. Data analysis conducted by researchers is descriptive descriptive analysis. Based on the results of the research above, it can be collected. The communication strategy used by psychologists in handling drug abuse victims at the Bali Provincial Mental Hospital is Before rehabilitating drug abuse victims. The psychologist first assumes the victim, to find out the victim's biography. Start how to communicate, the environment, the family of the victim. After receiving the victim's data, a psychologist will take action later. During the rehabilitation process psychologists always provide the communication messages they want to convey when they enter rehabilitation. It is to educate how to change and stop using drugs. In the rehabilitation process psychologists position themselves as friends or people they can trust by giving empathy to them to find out the root causes of the reasons why they use drugs and find out how to deal with the problem. When doing this rehabilitation process psychologists also have special tricks or therapies through holistic methods to determine the personal, environmental, and communication aspects of the victim. In addition, psychologists also have the $5 \mathrm{~B}$ method that is regular treatment always controls and checks urine, Communicating always conveying the problems they have, Activating activities that are positive, Recreation is always exercising, and Praying. The way psychologists know their own potential. By way of psychotest or aptitude tests and data collection about the victim's life history. With family. To build self-confidence in drug abuse victims to be accepted again in the community. By looking and notifying the potential that he has and being aware of its strengths. Communication barriers experienced by psychologists in handling drug abuse victims are difficult in families, friends, cellphones or technology, money.
\end{abstract}

\title{
Keywords: Communication Strategy, Psychologist, Drug Abuse Victim
}




\section{Pendahuluan}

Pergaulan di Indonesia sekarang banyak mulai mengikuti trend gaya barat. Dimana banyak kita temui masyarakat Indonesia yang memakai pakaian seksi, kebut-kebutan di jalan, memakai narkoba, mabuk- mabukan. Hal ini disebabkan karna faktor lingkungan dalam masyarakat dan keluarga yang tidak harmonis. Salah satu yang paling banyak menarik perhatian kita adalah banyaknya pengguna narkoba yang ada di Indonesia akibat dari besarnya pergaulan yang terjadi sekarang.Menurut data dari BNN sepanjang tahun 2015 BNN telah mengungkap sebanyak 102 kasus Narkotika dan TPPU yang merupakan sindikat jaringan nasional dan iternasional, dimana sebanyak 82 kasus. Kasuskasus yang telah diungkap tersebut melibatkan 202 tersangka yang terdiri dari 174 WNI dan 28 WNA. Dimana terdapat 55 orang terpidana kasus Narkotika yang mendapatkan vonis hukuman mati, dimana 14 orang terpidana mati kasus Narkotika diantaranya sedang menunggu eksekusi hukuman mati.

Pada tahun 2015 , BNN bersama lembaga rehabilitasi instansi pemerintah dan komponen masyarakat telah melaksanakan program rehabilitasi kepada 38.427 pecandu, penyalah guna dan korban penyalahgunaan Narkotika yang berada di seluruh Indonesia dimana sejumlah 1.593 direhabilitasi melalui Balai Besar Rehabilitasi yang dikelola oleh BNN, baik yang berada di LidoBogor, Baddoka- Makasar, Tanah- Merah- Samarinda, dan Batam - Kepulauan Riau. Angka tersebut mengalami peningkatan, dimana pada tahun sebelumnya hanya sekitar 1.1223 orang pecandu dan penyalah gunaan yang direhabilitasi.

Di Bali Penyalahgunaan Narkoba ternyata sangat menghawatirkan. Berdasarkan hasil penelitian BNN dan Universitas Indonesia dari 34 provinsi pada tahun 2014 bali berada di peringkat ke -8 dalam tingkat prevalensi pengguna narkoba di Indonesia yakni sebanyak 2.2\% yaitu sebanyak 66.785 jiwa dari total 3.088.900 jumlah penduduk Bali yang berusia 10-59 tahun. Dimana sekitar 8.000 pengguna narkoba di Bali berada padaa kota Denpasar dan yang sudah direhabilitasi sebanyak 37 pengguna narkoba. Oleh karena itu peran Rumah Sakit Jiwa provinsi Bali sangat membantu dalam proses merehabilitasi para pengguna narkoba. Sehingga masyarakat yang sudah terlanjur menggunakan Narkoba bias menjalani kehidupan mereka yang normal tanpa merasakan ketergantungan penggunaan narkoba lagi.

\section{a. Strategi Komunikasi}

\section{Definisi Strategi}

\section{Definisi Umum}

Strategi adalah proses penentuan rencana para pemimpin puncak yang berfokus pada tujuan jangka panjang organisasi, disertai penyusunan suatu cara atau upaya bagaimana agar tujuan tersebut dapat dicapai.

\section{Definisi khusus}

Strategi merupakan tindakan yang bersifat incremental (senantiasa meningkat) dan terus-menerus, serta dilakukan berdasarkan sudut pandang tentang apa yang diharapkan oleh para pelanggan di masa depan. Dengan demikian, strategi hampir selalu dimulai dari apa yang dapat terjadi dan bukan dimulai dari apa yang terjadi. Terjadinya kecepatan inovasi pasar yang baru dan perubahan pola konsumen yang memerlukan kompetensi inti(core competencies).

Perusahaan perlu mencari kompetensi inti di dalam bisnis yang dilakukan.

\section{Perumusan Strategi}


Perumusan strategi merupakan proses penyusunan langkah-langkah ke depan yang dimaksudkan untuk membangun visi dan misi organisasi, menetapkan tujuan strategis dan keuangan perusahaan.

\section{Tingkat-Tingkat Strategi}

Dengan merujuk pada pandangan Dan Schendel dan Charles Hofer, Higgins (1985) menjelaskan adanya empat tingkatan strategi.Keseluruhannya disebut Master Strategy, yaitu: enterprise strategy, corporate strategy, business strategy dan functional strategy.

\section{a) Enterprise Strategy}

Strategi ini berkaitan dengan respons masyarakat. Setiap organisasi mempunyai hubungan dengan masyarakat.

\section{b) Corporate Strategy}

Strategi ini berkaitan dengan misi organisasi, sehingga sering disebut Grand Strategy yang meliputi bidang yang digeluti oleh suatu organisasi. keputusan-keputusan stratejik dan perencanaan stratejik yang selayaknya juga disiapkan oleh setiap organisasi.

\section{c) Business Strategy}

Strategi pada tingkat ini menjabarkan bagaimana merebut pasaran di tengah masyarakat.

\section{d) Functional Strategy}

Strategi ini merupakan strategi pendukung dan untuk menunjang suksesnya strategi lain.

\section{Jenis-jenis Strategi}

Banyak organisasi menjalankan dua strategi atau lebih secara bersamaan, namun strategi kombinasi dapat sangat beresiko jika dijalankan terlalu jauh.:

\section{Strategi Integrasi}

Integrasi ke depan, integrasi ke belakang, integrasi horizontal kadang semuanya disebut sebagai integrasi vertikal. Strategi integrasi vertikal memungkinkan perusahaan dapat mengendalikan para distributor, pemasok, dan / atau pesaing.

\section{Strategi Intensif}

Penetrasi pasar, dan pengembangan produk kadang disebut sebagai strategi intensif karena semuanya memerlukan usaha-usaha intensif jika posisi persaingan perusahaan dengan produk yang ada hendak ditingkatkan.

\section{Strategi Diversifikasi}

Terdapat tiga jenis strategi diversifikasi, yaitu diversifikasi konsentrik, horizontal, dan konglomerat..

\section{Strategi Defensif}

Rasionalisasi Biaya, terjadi ketika suatu organisasi melakukan restrukturisasi melalui penghematan biaya dan aset untuk meningkatkan kembali penjualan dan laba yang sedang menurun.

\section{Strategi Umum Michael Porter}

Menurut Porter, ada tiga landasan strategi yang dapat membantu organisasi memperoleh keunggulan kompetitif, yaitu keunggulan biaya, diferensiasi, dan fokus.

\section{b. Komunikasi}

\section{Pengertian Komunikasi}

Kata atau istilah komunikasi ( dari bahasa inggris "communication")secara etimologis atau menurut asal katanya adalah dari bahasa Latin communicates, dan perkataan ini ini bersumber pada kata comunis dalam 
kata komunis ini memiliki makna 'berbagi' atau 'menjadi milik bersama' yaitu suatu usaha yang memiliki tujun untuk kebersamaan atau kesamaan makna. Jadi, komunikasi adalah suatu prosess penyampaian informasi \{pesan ,ide,gagasan) dari satu pihak kepada pihak lain.

\section{Fungsi Komunikasi}

Fungsi dari diadakannya komunikasi adalah :

1 Kendali : komunikasi bertindak untuk mengendalikan prilaku anggota dalam beberapa cara, setiap organisasi mempunyai wewenang dan garis panduan formal yang harus dipatuhi.

2 Motivasi : komunikasi membantu perkembangan motivasi dengan menjelaskan kepada seseorang apa yang harus dilakukan bagaimana merea bekerja baik dan apa yang dapat dikerjakan untuk memperbaiki kinerja jika itu dibawah standar.

3 Pengungkapan Emosional : bagi banyak orang dalam kelompok kerja mereka merupakan sumber utama untuk interaksi sosial, komunikasi yang terjadi didalam kelompok itu merupakan mekanisme fundamental dengan mana anggota-anggota menunjukkan kekecawaan dan rasa puas mereka oleh karena itu komunikasi menyiarkan ungkapan emosional dari perasaan dan pemenuhan kebetuhan sosial

4 Informasi : komunikasi memberikan informasi yang diperlukan individu dan kelompok untuk mengambil keputusan denganmeneruskan data guna mengenai dan menilai pilihan-pilihan alternative (Robbins,2002 :310-311)

\section{Komponen komunikasi}

Komponen komunikasi adalah hal-hal yang harus ada agar komunikasi bisa berlangsung dengan baik. Menurut Laswell komponen- komponen komunikasi adalah :

1 Pengirim atau Komunikator ( sender) adalah pihak yang mengirimkan pesan kepada pihak lain.

2 Pesan (message) adalah isi atau maksud yang akan disampaikan oleh satu pihak kepada pihak lain.

3 Saluran (channel) adalah media di mana pesan disampaikan kepada komunikan dalam komunikasi antar pribadi ( tatap muka) saluran dapat berupa udara yang mengalirkan getaran nada atau suara.

4 Penerima atau komunikate (receiver) adalah pihak yang menerima pesan dari pihak lain.

5 Umpan balik (feedback) adalah tanggapan dari penerimaan pesan atas isi pesan yang disampaikannya.

6 Aturan yang disepakati para pelaku komunikasi tentang bagimana komunikasi itu akan dijalankan ("Protokol").

\section{Proses Komunikasi}

Secara ringkas, proses berlangsungnya komunikasi bisa digambarkan seperti berikut.

1. Komunikator ( sender) yang mempunyai maksud berkomunikasi dengan orang lain mengirimkan suatu pesan kepada orang yang dimaksud. Pesan yang disampaikan itu bisa berupa informasi dalam bentuk bahasa ataupun lewat simbol-simbol yang bisa dimengerti dua belah pihak.

2. Pesan (message) itu disampaikan atau di bawa melalui suatu media atau saluran baik secara langsung maupun tidak langsung. Contohnya berbicara langsung lewat telepon,surat,email, atau media lainnya.

3. Media (channel) alat yang yang menjadi penyampai pesan dari komunikator ke komunikan.

4. Komunikan (receiver) menerima pesan yang disampaikan dan menerjemahkan isi pesan yang diterimanya kedlam bahasa yang dimenegrti oleh komunikan itu sendiri.

5. Komunikan ( receiver) memberikan umpan balik (feedback) atau tanggapan atas pesan yangdikirimkan kepadanya, apakah dia mengerti atau memahami pesan yang dimaksud oleh pengirim. 


\section{Model-model komunikasi}

Dari berbagai model komunkiasi yang sudah ada, disini akan dibahas tiga model paling utama, serta akan dibicarakan pendekatan yang mendasarinya dan bagimana komunikasi dikonseptualisasikan dalam perkembangannya.

\section{Model Komunikasi Linear}

Model komunikasi ini ditemukan oleh Claude Shannon dan Warren Weaver pada Tahun 1949 dalam buku The Mathematical of Communication. Mereka mendeskripsikan komunikasi sebagai proses linear karena tertarik pada teknologi radio dan telepon an ingin mengembangkan suatu model yang dapat menjelaskan bagaimana informasi melewati berbagai saluran (channel). Hasilnya adalah konseptualisasi dari komunikasi linear ( linear communication model). Pendekatan ini terdiri atas beberapa elemen kunci : sumber (source), pesan (massage) dan penerima (receiver).

\section{Model Interaksional}

Model interaksional dikembangkan oleh Willbur Schramm pada tahun 1954 yang menekankan pada proses komunikasi dua arah diantara para komunikator. Dengan kata lain komunikasi berlangsung dua arah : dari pengirim dan kepada penerima dan dari penerima kepada pengirim.. proses melingar ini menunjukkan bahwa komunikasi selalu berlangsung.

\section{Model Transaksional}

Model komunikasi transaksional dikembangkan oleh Barnlund pada tahun 1970. Model ini menggaris bawahi pengiriman dan penerimaan pesan yang berlangsung secara terus menerus dalam sebuah proses kooperatif : pengirim dan penerima sama-sama bertanggung jawab terhadap dampak dan efektivitas komunikasi yang terjadi. Model transaksional berasumsi bahwa saat kita erus-menerus mengirimkan dan menerima pesan, kita berurusan baik dengan elemen verbal dan non verbal. Dengan kata lain, peserta komunikasi (komunikator) melakukan proses negosiasi makna.

\section{Faktor Komunikasi}

Faktor-faktor yang mempengaruhi komunikasi diantaranya :

\section{Latar Belakang Budaya}

Interpretasi suatu pesan akan terbentuk dari pola piker seseorang melalui kbiasaanya, sehingga semakin sama latar belakang budaya antara komunikator dengan komunikan maka komunikasi semakin efektif.

\section{Ikatan kelompok atau group}

Nilai-nilai yang dianut oleh uatu kelompok sangat mempengaruhi cara mengaamaati pesan.

\section{Harapan}

Harapan mempengaruhi penerimaan pesan sehingga dapat menerima pesan sesuai dengan yang diharapkan.

\section{Pendidikaan}

Semakin tinggi pendidikan akan semakin kompleks sudut pandang dalam menyikapi isi pesan yang disampaikan. 


\section{Situasi}

Perilaku manusia dipengaruhi oleh lingkungan atau situasi.

\section{Strategi Komunikasi}

Mensosialisasikan perubahan corporate identity diperlukan strategi, seperti yang diungkapakan oleh Onong Uchjana (2003:299) bahwa berhasil atau tidaknya sebuah kegiatan komunikasi secara efektif banyak ditentukan oleh strategi komunikasi.

Berkaitan dengan keterangan diatas, Mintzberg dan Quinn berpendapat bahwa strategi berkaitan dengan 5 hal:

1. Strategy as a plan: strategi merupakan suatu rencana yang menjadi pedoman bagi organisasi untuk mencapai sasaran dan tujuan yang telah ditetapkan.

2. Strategy as a pattern: strategi merupakan cara organisasi atau pola tindakan konsisten yang dijalankan organisasi dalam jangka waktu yang lama.

3. Strategy as a position: strategi merupakan cara organisasi dalam menempatkan sesuatu pada tempat yang tepat.

4. Strategy as a perspective: strategy merupakan cara pandang organisasi dalam menjalankan berbagai kebijakan. Cara pandang ini berkaitan dengan visi dan misi budaya organisasi.

5. Strategy as a play: cara atau manufer yang spesifik yang dilakukan organisasi dengan tujuan untuk mengalahkan rival atau kompetitor.

Quinn mengemukakan bahwa suatu strategi yang efektif meliputi 3 elemen yang penting yaitu:

1. Tujuan utama organisasi.

2. Berbagai kebijakan yang mendorong justru membatasi gerak organisasi.

3. Rangkaian aktivitas kerja atau program yang mendorong terwujudnya tujuan organisasi yang telah ditentukan dalam berbagai keterbatasan.

\section{Sasaran Komunikasi.}

Sebelum melancarkan komunikasi perlu mempelajari siapa yang kan menjadi sasaran komunikasi., yang meliputi:

a. Kondisi kepribadian dan kondisi fisik khalayak yang terdiri dari:

1. pengetahuan khalayak mengenai pokok persoalan.

2. kemampuan khalayak untuk menerima pesan-pesan lewat media yang digunakan.

b. pengetahuan khalayak terhadap perbendaharaan kata-kata yang digunakan. Pengaruh kelompok dan masyarakat serta nilai-nilai dan noma-norma kelompok dan masyarakat yang ada.

c. Situasi dimana khalayak itu berada. (Marhaeni Fajar, 2009:184).

\section{Penyusunan Pesan/Strategi Pesan}

Setelah mengenal khalayak dan situasinya, maka langkah selanjutnya dalam peumusan strategi ialah menyusun pesan, yaitu menentukan tema dan materi. Syarat utama dalam mempengaruhi khalayak dari pesan tersebut, ialah mampu membangkitkan perhatian.

Berkaitan dengan isi pesan, Marhaeni fajar (2009: 195-196) menerangkan terdapat dua bentuk penyajian isi pesan, yakni meliputi: 
a. One side issue (sepihak): dimaksudkan sebagai penyajian masalah yang bersifat sepihak yaitu mengemukakan hal-hal positif saja ataukah hal-hal negatif saja kepada khalayak permasalahan itu berisi konsepsi komunikator semata-mata tanpa mengusik pendapat yang telah berkembang.

b. Both side issue (kedua belah pihak): sesuatu yang disajikan baik negatifnya maupun positifnya. Juga dalam mempengaruhi khalayak, permasalahan itu diketengahkan baik konsepsi dari komunikator maupun konsepsi dari kabar/pendapat yang telah berkembang pada khalayak.

\section{Menetapkan Metode}

Marheni Fajar (2009: 197-203) menjelaskan bahwa mencapai efektifitas dari suatu komunikasi selain bergantung pada kemantapan isi pesan yang diselaraskan dengan kondisi khalayak dan sebagainya, maka juga akan turut dipengaruhi oleh metode-metode penyampaianya kepada sasaran dapat diwujudkan dalam dua bentuk yaitu metode.

a. Repetition : merupakan cara mempengaruhi khalayak dengan jalan mengulang pesan sedikit demi sedikit, seperti yang dilakukan dalam propaganda. Metode ini memungkinkan peluang mendapatkan perhatian khalayak semakin besar, pesan penting mudah diingat oleh khalayak dan memberi kesempatan bagi komunikator untuk memperbaiki kesalahan yang dilakukan sebelumnya.

b. Canalizing : dilakukan dengan cara komunikator berusaha memahami dahulu soal komunikan seperti kerangka referensi dan bidang pengalamn komunikan, kemudian menyusun pesan dan metode yang sesuai dengan hal itu. Hal itu bertujuan agar pesan dapat diterima terlebih dahulu baru kemudian dilakukan perubahan-perubahan sesuai dengan keinginan komunikator.

c. Informative : mempengaruhi khalayak dengan jalan memberikan penerangan yakni memberikan sesuatu apa adanya sesuai dengan fakta dan data maupun pendapat yang sebenarnya.

d. Persuasive : mempengaruhi komunikan dengan jalan membujuk. Dalam hal ini komunikan tidak diberi kesempatan untuk berpikir kritis dan bila mungkin akan terpengaruh tanpa disadari.

e. Educative : mempengaruhi khalayak dengan pesan-pesan yang bersifat mendidik, yakni memberikan suatu ide kepada khalayak berdasarkan fakta, pendapat dan pengalaman yang dapat dipertanggungjawabkan kebenarannya. Dengan metode edukatif ini akan memberikan pengaruh yang mendalam kepada khalayak kendatipun hal ini akan memakan waktu yang sedikit lebih lama dibanding dengan metode persuasive.

f. Coersive : mempengaruhi khalayak dengan pemaksaan, pesan-pesan yang disampaikan biasanya mengandung ancaman atau intimidasi. Metode ini biasanya diwujudkan dalam bentuk paraturan-peraturan, perintah-perintah dan intimidasi.

\section{Pemilihan Media Komunikasi/Strategi Media.}

Menurut Onong Uchjana Effendy (2007:37), untuk mencapai sasaran komunikasi kita dapat memilih salah satu atau gabungan dari beberapa media, bergantung pada tujuan yang akan dicapai, pesan yang akan disampaikan, dan teknik yang akan dipergunakan, Mana yang terbaik dari sekian banyak media komunikasi itu tidak dapat ditegaskan sebab masing-masing memiliki kelebihan dan kekurangan. Simmons dalam bukunya Communication Campaign Management (138) menyatakan bahwa ada beberapa hal yang harus diperhatikan agar penggunaan media bisa efektif, yaitu:

a. Mass media advantages \& disadvantages, setiap tipe media memiliki karakteristik yang berbeda. Dengan mengetahui kelebihan dan kekurangannya maka pemilihan media dapat dilakukan sesuai kebutuhan.

b. Matching media \& audience segment. Dalam hal ini manager atau planner harus mampu menentukan media 
mana yang bisa menyampaikan pesan sesuai dengan karakteristik khalayak yang dituju. Untuk itu dibutuhkan analisis khalayak secara komprehensif.

c. The concept of reach. Frekuensi menunjuk pada jumlah pengulangan pesan dalam sebuah periode waktu (empat minggu), untuk meningkatkan terpaan pada khalayak sasaran. Dalam sebuah kelompok dimungkinkan beberapa individu lebih banyak mendapat terpaan pesan daripada yang lainnya.

d. Reach \& frequency trade-offs. Ketika jangkauan dan frekuensi dioperasikan secara bersama-sama mungkin akan terhambat oleh keterbatasan dana. Terlebih kalau harus membayar waktu atau space media atau menyewa biro jasa dibidang media. Oleh karena itu untuk menghemat biaya, bila jangkauan diperluas maka frekuensi dikurangi, demikian sebaliknya.

\section{Komunikator/Strategi Komunikator.}

Menurut Onong Uchjana Effendy (2003: 43-45), ada tiga faktor penting yang harus diperhatikan komunikator agar komunikasi dapat berjalan denga lancar. Yaitu daya tarik sumber, kredibilitas sumber, dan kemampuan berempati:

a. Daya tarik sumber (source attractiveness): komunikator akan mampu mengubah sikap, pendapat, dan perilaku khalayak bila ia mampu menarik perhatian khalayak. Rakhmat meyatakan khalayak cenderung menyukai orang yang tampan atau cantik (faktor fisik), mempunyai banyak kesamaan dengan dirinya dan memiliki kemampuan yang lebih tinggi.

b. Kredibilitas sumber (source credibility): dalam hal ini kredibilitas sumber menurut Ariffin merujuk pada kepercayaan komunikan kepada komunikator. Kepercayaan itu tergantung pada:

1. kemampuan dan keahlian komunikator berkaitan dengan isi pesan yang disampaikan.

2. Kemampuan dan ketrampilan menyajikan pesan dalam arti memilih tema, metode dan media, sesuai dengan situasi..

3. Memiliki budi pekerti dan lepribadian baik dan disegani oleh khalayak.

4. Memiliki keakraban dan hubungan baik dengan khalayak.

Selain daya tarik dan kredibiltas sumber, komunikator juga dituntut untuk mampu berempati . Selanjutnya, seorang komunikator akan sukses dalam bekomunikasi kalau ia menyesuaikan komunikasinya dengan the image dari komunikan. Yaitu memahami kepentinganya, kebutuhanya, kecakapanya.

\section{c. Sosialisasi Corporate Identity.}

Mensosialisasikan dalam hal ini merupakan sebuah aktivitas komunikasi atau mengkomunikasikan sesuatu. Upaya perusahaan untuk dapat mengkomunkasikan perubahan corporate identity tentu tidak dapat dilepaskan dari kegiatan berkomunikasi. Komunikasi berasal dari bahasa Latin: communicatio yang memiliki arti pemberitahuan, atau pertukaran pikiran. Sementara itu proses komunikasi dapat diartikan sebagai transfer informasi atau pesan-pesan dari pengirim pesan sebagai komunikator dan penerima pesan sebagai komunikan, dalam proses komunikasi tersebut untuk mencapai saling pengertian antara kedua belah pihak. Rosady Ruslan (2001:77). Pentingnya komunikasi dalam perubahan sudah jelas untuk menimbulkan persesuaian paham dibenak publik, membantu orang untuk memahami mengapa perubahan dilakukan, membantu mereka melewati masa transisi, memecahkan berbagai masalah yang muncul, membuat orang terlibat dan ikut merasa bertanggungjawab, semua itu berkaitan dengan komunikasi, (Manchester Open Learning, 1994:70). Adapun tujuan komunikasi lewat pesan-pesan yang disampaikan dalam mensosialisasikan sesuatu terbagi menjadi empat menurut Marhaeni Fajar (2009:60-61): 
1. Efek Kognitif/perubahan pendapat: dalam komunikasi berusaha menciptakan pemahaman yang dalam hal ini ialah kemampuan memahami pesan secara cermat sebagaimana dimaksudkan oleh komunikator. Setelah memahami apa yang dimaksud komunikator maka akan tercipta pendapat yang berbeda-beda bagi komunikan.

2. Efek Afektif/Perubahan Sikap: seorang komunikan setelah menerima pesan kemudian sikapnya berubah, baik positif maupun negatif.

3. Efek Perilaku: komunikasi bertujuan untuk mengubah peilaku maupun tindakan seseorang.

4. Perubahan Sosial: membangun dan memelihara ikatan hubungan dengan orang lain sehingga menjad hubungan yang makin baik.

Seperti telah disebutkan diatas, bahwa usaha komunikasi menimbulkan beberapa efek bagi penerimanya, mensosialisasikan perubahan ini lewat pesan yang disampaikan dan media untuk penyampaian pesan mengacu pada terciptanya efek kognitif. Menurut Belch George \& Belch Michael, (1993:199-200) komponen-komponen dalam efek kognitif yaitu:

a. Awarenees (kesadaran)

Jika sebagaian besar audience sasaran tidak menyadari merek atau prosuk atau jasa, yang ditawarkan, tugas perusahaan adalah membangun kesadaran. Kesadaran berarti bahwa pesan yang telah dibuat menimbulkan kesan kepada pembaca atau penonton yang kemudian dapat membantu mengidentifikasi pembuat pesan. 34

b. Knowledge (pengetahuan)

Audience mungkin telah memiliki kesadaran, tetapi tidak mengetahui lebih banyak lagi. Pada tahapan ini perusahaan memiliki tugas untuk memberikan informasi sebanyak-banyaknya sehingga audience sasaran memiliki "pengetahuan tentang produk, manfaat, faedah guna, dan keuntungan, serta bagaimana cara menggunakan produk". (Wells, 2005:157). . Karena ini berkaitan dengan media yang harus digunakan. Dibawah ini terdapat dua tatanan dalam menentukan efek apa yang ingin dicapai:

a. Komunikasi Tatap Muka: komunikasi tatap muka dipergunakan apabila kita mengharapkan efek perubahan tingkah laku (behaviour change) dari komunikan. Mengapa demikian, karena sewaktu berkomunikasi memerlukan umpan balik langsung. Dengan saling melihat, kita sebagai komunikator bisa mengetahui pada saat kita berkomunikasi komunkan memperhatikan kita dan mengerti apa yang kita komunikasikan.

b. Komunikasi Bermedia: pada umumnya banyak digunakan untuk komunikasi informatif. Ketika tidak memerlukan efek dalam bentuk perubahan tingkah laku, maka dapat digunakan atau diambil media massa, jadi, tergantung dari situasi dan kondisi dan efek yang diharapkan. (Onong Uchjana Effendy, 2003:302-303).

Dalam usaha untuk mensosialisasikan juga terdapat cara atau strategi yang digunakan. Strategi sosialisasi yang dapat dilakukan menurut Susanto ( 1997 : 47-48 ) adalah:

a. In House Campaign: Proses sosialisasi yang diarahkan pada seluruh anggota organisasi didalam perusahaan, yang menyangkut semua tingkatan yang ada dalam aktivitas kerja sehari - hari.

b. Outside Campaign: Seluruh proses sosialisasi diarahkan pada lingkungan ekstern organisasi

\section{d. Psikologi}

\section{Pengertian Psikolog}

Psikolog adalah seorang ahli dibidang pratik psikologi, bidang ilmu pengetahuan yang mempelajari 
tingkah laku dan proses mental. Psikolog dapat dikategorikan kedalam beberapa bidang tersendiri seeuai dengan cabang ilmu psikologi yang ditekuninya, misalnya psikologi klinis,psikolog pendidikan psikolg industry. Tetapi kata "psikolog" lebih sering digunakan untuk menyebut alih psikologi klinis, ahli psikologi dibidang kesehatan mental. Psikolog di Indonesia tergabung dalam organisasi profesi yang bernama HIMPSI (Himpunan Psikologi Indonesia).

\section{Jenis-jenis Psikolog}

1 Psikologi Anak

Psikolog anak membantu anak-anak dan keluaga mengatasi masalah pilaku yang sulit.

\section{Psikologi Klinis}

Mempelajari seluk beluk penilaian psikologis dan mengobati pasien dari segaa usia dan jenis menggunakan teknik psikoterapi yang telah teruji muthakir.

\section{Psikologi Forensik}

Berada antara bidang psikologi dan hukum. Mereka berprofesi sebagai psikolog forensic data bekerja dalam penanganan diskriminasi karyawan, hak asuh anak, dan menilai seseorang apakah pantas untuk diadili.

\section{Neuropsikolog}

Lebih banyak bekerja dibagian laboratorium daripada spesialis psikologi lainnya, psikolog mempelajari aspek fisik dari otak dan bagaimana mereka mempengaruhi prilaku.

\section{Psikolog Profesional Sekolah}

Bekerja dilapangan dengan berhadapan langsung dengan anak-anak untuk mendiagnosa daan mengobati masalah prilaku dan emosional, tetapi juga bekerja dengan guru dan adsministrator pendidikan. Seseorang pskolog sekolah bekerja untuk membuat rencana peningkatan kerja siswa pendidik.

\section{Psikologi Komunikasi}

Menurut Fisher dalam bukunya Jalaludin Rahmat pendekatan psikologi komunikasi memiliki empat ciri-ciri, yaitu:

a. Penerimaan Stimuli Secara Inderawi (Sensory Reception of Stimuly).

Pada proses ini komunikasi diawali atau bermula ketika panca indra kita diterpa oleh stimuli, panca indra tersebut yakni mata, hidung, telinga, kulit, dan mulut. Stimuli bisa berbentuk orang, pesan, suara, warna, dan sebagainya; pokoknya segala hal yang mempengaruhi kita.

b. Proses yang Mengantarai Stimuli dan Respons (Internal Mediation Of Stimuli).

Pada ciri pendekatan ini, stimuli yang ditangkap oleh alat indera, kemudian diolah dalam otak. Kita hanya mengambil kesimpulan tentang proses yang terjadi pada otak dari respons yang tampak. Melalui tanda-tanda yang diketahui, seperti tersenyum, tepuk tangan, dan meloncat-loncat, yang memiliki arti sedang gembira.

c. Prediksi Respons (Prediction of Response).

Pada pendekatan ciri ini, Respons yang terjadi pada masa lalu dapat dapat dilihat serta dapat diramal responya untuk masala mendatang. Kuncinya, harus mengetahui sejarah respons terdahulu, sebelum meramalkan respons individu saat ini.

\section{d. Peneguhan Response (Reinforcement of Response)}

Pada pendekatan ciri ini timbul perhatian pada gudang memori (memori storage) dan set (penghubung masa lalu dan masa sekarang). Salah satu unsur sejarah respons ialah peneguhan. Peneguhan adalah respons lingkungan 
(atau orang lain pada respons organisme yang asli). Berger dan Lambert menyebutnya feedback (umpan balik), tetapi Fisher tetap menyebutnya Peneguhan.

\section{Teori Psikologi Tentang Manusia}

Karena psikologi komunikasi berkaitan dengan bagaimana mencapai komunikasi yang efektif dalam interaksi manusia maka menjadi penting untuk diketahui tentang manusia itusendiri. Setiap manusia mengandung misteri kehidupannya masing-masing. Secara lebih khusus, terdapat empat teori psikologi tentang manusia.

\section{a. Psikoanalisis}

Sigmund Freud, pendiri psikoanalisis memfokuskan perhatian kepada totalias kepribadian manusia, bukan pada bagian-bagiannya yang terpisah.

\section{b. Behaviorisme}

Lahir sebagai reaksi terhadap instropeksionisme (yang menganalisa jiwa manusia berdasarkan laporan-laporan subjektif) dan juga psikoanalisis. Behaviorisme hanya ingin menganalisa perilaku yang tampak saja, yang dapat diukur, dilukiskan dan diramalkan.

\section{c. Kognitivisme}

Disini muncul paradigma baru bahwa manusia tidak lagi dipandang sebagai makhluk yang bereaksi secara pasif pada lingkungan tapi sebagai makhluk selalu memahami lingkungannya, makhluk yang selalu berpikir (homo sapiens). Sebagai contoh, apakah penginderaan kita melalui pengalaman langsung, sanggup memberikan kebenaran. Kemampuan alat indera kita dipertanyakan karena seringkali gagal menyajikan informasi yang akurat.

\section{Korban Penyalahgunaan Narkoba}

Korban berasal dari bahasa Arab yang artinya juga menurunkan kata kurban. Korban berarti "orang atau binatang yang menderita atau mati akibat suatu kejadian, perbuatan jahat, dan sebagainya", sedangkan kurban berarti "persembahan kepada Tuhan atau pemberian untuk menyatakan kesetiaan atau kebaktian". Tindakan kejahatan menimbulkan korban (disebut sebagai "korban kejahatan").

\section{Penggolongan Narkoba}

Penggunaan dan peredaran Narkoba diatur dalam Undang-Undang, yaitu Undang-Undang Nomor 5 tahun 1997 tentag Psikotropika. Penggolongan jenis-jenis narkoba berikut didasarkan pada peraturan perundang-undangan yang berlaku.

1. Narkotika adalah zat atau obat yang berasal dari tanaman atau bukan tanaman baik sintetis maupun semi yang dapat menyebabkan penurunan atau perubahan kesadaran ,menghilangkan ataupun mengurangi rasa nyeri. Menurut Undang-undang nomor 22 tahun 1997, narkotika dibagi menurut potensi yang menyebaban ketergantungan adalah sebagai berikut :

a. Narkotika golongan I : berpotensi sangat tinggi menyebabkan ketergantungan . tida digunakan untuk terapi (pengobatan). Contoh : heroin dan kokain.

b. Narkotika golongan II : berpotensi tinggi menyebabkan ketergantungan. Digunakan pada terapi sebagai pilihan terakhir. Contoh : morfin dan metadon.

c. Narkotika golongan III : berpotensi ringan menyebabkan ketergantungan dan banyak digunakan dalam terapi. Contoh : kodein.

2. Psikotropika merupakan zat atau obat, baik alamiah maupun sintetis bukan narkotika yang berkhasiat 
psikoaktif melalui pengaruh seektif pada susunan saraf pusat dan menyebabkan perubahan khas pada aktivitas mental dan prilaku, yang dibagi menurut potensi yang dapat menyebabkan ketergantungan:

a. Psikotropika golongan I : amat kuat menyebabkan ketergantungan dan tida digunakan dalam terapi. Contoh : LSD dan STP

b. Psikotropika golongan II : kuat menyebabkan ketergantungan, digunakan amat erbatas pada terapi. Contoh : Amfetamin dan Ritelin

c. Psikotropika golongan III : potensi sedang menyebabkan ketergantungan, banyak diguakan dalam terapi. Contoh : Pentobarbital dan Flunitrazepam.

d. Psikotropika golongan IV : poteni ringan dapat menyebabkan ketergantungan dan sangat luas digunakan dalam terapi. Contoh : Diazepam dan Klorazepam.

3. Zat Psiko-AktifLain Merupakan zat atau bahan lain bukan narkotika dan psikotropika yang berpengaruh pada kerja otak. Tidak tercantum dalam peraturan perundang-undangan tentang Narkotika dan Psikotropika yang sering disalahgunakan adalah :

a. Alkohol : terdapat pada berbagai minuman keras

b. Inhalansia/solven : gas atau zat yang mudah menguap yang terdapat pada berbagai keperluan pabrik, antor dan rumah tangga

c. Nikotin : terdapat pada tembaau

Kafein : terdapat pada kopi ,minuman penambah energi, dan obat sakit kepala tertentu.

\section{Metode penelitian}

\section{Lokasi Penelitian}

Lokasi penelitian ini bertempat di Rumah Sakit Jiwa Provins Bali di Jalan Kusuma Yudha No.29 Bangli.

\section{Pendekatan dan Rancangan Penelitian}

\section{Pendekatan Penelitian}

Pendekatan yang dilakukan dengan penelitian ini adalah pendekatan kualitatif

\section{Rancangan Penelitian}

Rancangan penelitian yang dilakukan dalam penelitian adalah rancangan studi kasus yaitu riset yang mendalam strategi komunikasi dalam menangani korban penyalahgunaan narkoba.

\section{Identifikasi dan Definisi Konsep}

\section{Identifikasi Konsep}

1. Strategi komuikasi psikolog

2. Penanganan Korban Penyalahgunaaan Narkoba

\section{Definisi Konsep}

1. Strategi komunikasi adalah langkah-langkah strategi yang digunakan oleh psikolog dalam menangani korban penyalahgunaan narkoba di Rumah Sakit Jiwa provnsi Bali..

2. Korban Penyalahgunaan Narkoba adalah orang yang telah mengunakan narkoba yang tidak dipergunakan untuk kegiatan pengobtan.

\section{Subjek Penelitian}

Dalam penelitian ini peneliti memilih dua orang psikolog menjadi informan. Berdasarkan beberapa 
pertimbangan yaitu informan yang dipilih peneliti adalah orang yang paling tahu dan menguasai tentang apa yang peneliti ingin teliti. Yaitu bapak mad basri selaku kepala ruang balai psikologi dan ibu ni gusti ketiit Diana setiawati,M.Psi. selaku psikolog klinis di Rumah Sakit Jiwa Provinsi Bali.

\section{Sumber Data}

\section{Data Primer}

Data primer adalah sumber data yang langsung memberikan objek data kepada pengumpul data. Data primer diperoleh dengan cara observasi,wawancara,dan dokumentasi dengan pihak Rumah Sakit Jiwa Provinsi Bali.

\section{Data Sekunder}

Data sekunder adalah sumber data yang tidak langsung memberikan data kepada pengumpulan data , misalnya lewat orang laib atau lewat dokumen. Data sekunder antara lain disajikan daam bentuk data-data, table-tabel, diagram-diagram, atau mengenai topik penelitian. Data ini merupakan data yang berhubungan secara langsung dengan penelitian yang dilaksankan dan bersumber dari Rumag Sakit Jiwa Provinsi Bali.

\section{Teknik dan Instrumen Pengumpulan Data}

\section{Wawancara}

Proses tanya jawab secara langsung antara peneliti dengan subjek penelitian untuk mendapat informasi yang dibuthkan untuk peneitian.

\section{Observasi}

Teknik pengumpulan data yang diperoleh serta dilaksanakan dengan cara mengamati bagaimana strategi komunikasi dalam menangani angka korban penyalahgunaan Narkoba di Rumah Sakit jiwa Provinsi Bali.

\section{Dokumen}

Upaya pengumpulan data dan teori melalui buku-buku, dokumen, serta informai lainnya baik di lokasi penelitian maupun yang ada di luar lokasi penelitian sebagai pengunjung penelitian (seperti dokumen, agena,hasil penelitian, dan catatan).

\section{Teknik Analisis Data}

Teknik analisis data yang penulis gunakan adalah metode deskriptif kualitatif, yaitu mendiskripsikan serta menganalisa data yang telah diperoleh dan selanjutnya dijabarkan dalam bentuk penjelasan sebenarnya.

\section{Hasil Penelitian}

Dalam proses penelitian ini menggunakan metode kualitatif, yang dimana pada penelitian ini mengambil 2 sample psikolog pada Rumah Sakit Jiwa Provinsi Bali. Dengan demikian analisis yang digunakan adalah mendeskripsikan jawaban responden terhadap pertanyaan yang diajukan mengenai strategi komunikasi psikolog dalam penanganan korban penyalahgunaan narkoba di Rumah sakit Jiwa Provinsi Bali.

Di Rumah Sakit Jiwa Provinsi Bali Pasieen penyalahgunaan narkoba di tempatkan di Ruang Dharmawangsa yang dimana diruangan ini terdapat sebanyak 18 tempat tidur yang diisi oleh 6 orang pasien. Pasien penyalahgunan narkoba di ruangan tersebut kebanyakan korban pengguna Shabu-shabu termasuk daalm narkotika golongan I. Dalam proses rehabilitasi ada 2 jalur yaitu :

1. Jalur Mandiri, dimana si koban ini memiliki inisiatf tersendiri daataang ke rumah sakit untuk direhabilitasi.

2. Jaalur hukum, dimana si korban ini merupakaan orang yng ditangkap oleh pihak berwenang dan dijatuhi 
hukuman untuk direhabilitasi olh pengadilan

\section{Strategi Menentukan Khalayak}

Sebelum melakukan rehabilitasi pasien korban penyalahgunaan narkoba. Psikolog terlebih dahulu melakukan assement kepaaa si korban, untuk mengetahui riwayat hidup korban. Mulai cara berkomunikasi,lingkungan,keluarga si korban. Setelah mendapaatkan data si korban, barulah nantinya akan diambil tindakan oleh psikolog.

\section{Strategi Penyampaian Pesan}

Selama proses rehabilitasi psikolog selalu memberikan pesan-pesan komunikasi yang ingin disampaikaan saat mereka memasuki masa rehabilitasi. Berupa memberikan edukasi bagaimana caranya untuk berubah serta berhenti menggunakan narkoba, selain itu juga psikolog memberitahukan tentang bahaya nnarkoba dan sejenisnya yang dimana menyebabkan efek ketergantungan bagi korban dan keluarga.

\section{Strategi Sebagai Komunikator}

Didalam proses rehabilatasi psikolog memposisikan diri sebagai teman atau orang yang bisa mereka percayai dengan memberikan empati kepada mereka untuk mencari tahu akar permasalahan dari penyebab mengapa mereka menggunakan narkoba dan mencari tahu bagaimana cara dia untuk mengatasi masalahnya. Jika psikolog menemukan korban penyalahgunaan narkoba kembai lagi ke pust rehabilitasi. Psikolog melakukan pendataan untuk mencari tau penyebab mengapa dia memakai narkoba kembali. Lalu memberikan edukasi kembali kepada si korban.

Tindakan komunikasi yang dilakukan psikolog, jika si korban mngalami luapan emosi yang tinggi dengan cara memberikan terapi otik. Terapi otik ini diberikaan agar si pasien ini merasa aman dan tidak emosi. Selain itu si korban juga diberikan waktu untuk meluapkan emosinya sehingga si korban merasa relax, setelah si korban relax selanjutnya diberikan relaxasi untuk mengontrol dirinya.

\section{Metode atau pendekatan Komunikasi}

Pendekatan komunikasi yang digunakan selama proses rehabilitasi dengaan cara melakukan pendataan tentanng si korban meneentukan tahap dalam proses rehabilitasi yaitu :

1. Tahap prekamtemplasi : tahap dimana si korban merasa bimbang antara ingin di rehabilitasi atau tidak

2. Tahap Kotemplasi : tahap dimana si korban merasa ingin berubah

3. Tahap Action : tahap ini dilakukan saat si korbn sudah mulai bertindak dan berkomitmen untuk berubah

4. Tahap maintance : Tahap ini dilakukan saat si korban sudah pulih dan menjaga diri mereka tetap bersih Selain itu psikolog melakukan pendekaatan untuk memodifikasi prilaku dengan menggunakan 3 aspek yaitu :

1. Aspek Tanggung jawab : digunakan untuk mengubah si korban dari yang pasif menjadi aktif

2. Aspek Disiplin; ini digunakan untuk mengubah prilaku yang dari tidak disiplin menjadi disiplin

3. Aspek Jujur : ini dilakukan untuk mengubah prilaku yang sering berbohong menjadi jujur

Jika psikolog menemukan kasus dalam satu keluarga menggunakan narkoba. Si psikolog menggunakan terapi otik, lalu melakukan intropeksi diri masing-masing mengapa menggunakan narkoba serta memisahkan korban tersebut. Contoh antara anak dengan orang tua atau ayah dengan ibu.

Saat melakukan proses rehabilitasi ini psikolog juga memiliki trik atau terapi khusus melalui metode holistic ( menyeluruh ) untk mementukan aspek pribadi,lingkungan, serta komunikasi si korban. Selain itu juga 
psikolog juga memiliki metode 5B yaitu :

1. Berobat teratur selalu melakukan kontrol dan cek urine

2. Berkomunikasi selalu menyampaikan masalaah yang mereka miiliki'

3. Beraktifitas melakukan kegiatan-kegiatan yang yang positif

4. Berekreasi selalu berolahraga

5. Berdoa

\section{Strategi Mengenal Komunikan}

Cara psikolog mengetahui potensi diri dari diri mereka sendiri. Dengan cara psikotest atau tes minat bakat dan melakukan pendataan tentang riwayat hidup si korban.dengan keluarga. Untuk membangun kepercayaan diri korban penyalah gunaan narkoba agar mau diterima kembali dalam lingkungan masyarakat. Dengan caramelihat dan memberitahukan potensi diri yang dia miliki serta sadari akan kelebihannya. Lalu mengedukasi keluarga korban untuk menghargai korban penyallah gunaan narkoba.

\section{Kendala atau Hambatan komunikasi yang dialami Psikolog dalaam penanganan korban Penyalaahgunaan Narkoba}

Hambatan atau kendala yang ditemui Psikolog dalam menangangi korban penyalahgunaan narkoba yaitu :

1. Kesulitan di dalam keluarga , keluarga merupakan faktor penyebab seseorang menggunkan narkoba. Itu dikarenakan tuntutan keluarga kepada si korban sangat besar dan juga seringnya terjadi konflik didalam keluarga.

2. Teman, ini disebabkan karena faktor lingkungan si korban yang juga sebagai pengguna narkoba. Sehingga si korban juga ikut menggunakan narkoba untuk bisa diterima oleh teman-temannya

3. HP atau Teknologi, semakin maju era teknologi pada saat ini si pengguna sangat mudah untuk mencari tahu tentang semua informasi pembelian dan penjualaan narkoba.

4. Uang, ini dikaarenaan si korban memiliki banyak uang sehingga korban meraasa sangat mudah dan gampang untuk mendapatkaan Narkoba.

\section{Kesimpulan dan Saran}

Berdasarkan dari hasil penelitian yang dikemukanaan maka dapat disimpulkan bahwa :

Strategi komunikasi yang digunakan psikolog dalam penanganan korban penyalahgunaan narkoba di Rumah Sakit Jiwa Provinsi Bali adalah Sebelum melakukan rehabilitasi pasien korban penyalahgunaan narkoba. Psikolog terlebih dahulu melakukan assement kepada si korban, untuk mengetahui riwayat hidup korban. Mulai cara berkomunikasi,lingkungan,keluarga si korban. Setelah mendapaatkan data si korban, barulah nantinya akan diambil tindakan oleh psikolog. Selama proses rehabilitasi psikolog selalu memberikan pesanpesan komunikasi yang ingin disampaikaan saat mereka memasuki masa rehabilitasi. Berupa memberikan edukasi bagaimana caranya untuk berubah serta berhenti menggunakan narkoba. Didalam proses rehabilatasi psikolog memposisikan diri sebagai teman atau orang yang bisa mereka percayai dengan memberikan empati kepada mereka untuk mencari tahu akar permasalahan dari penyebab mengapa mereka menggunakan narkoba dan mencari tahu bagaimana cara dia untuk mengatasi masalahnya. Saat melakukan proses rehabilitasi ini psikolog juga memiliki trik atau terapi khusus melalui metode holistic ( menyeluruh ) untk mementukan aspek pribadi,lingkungan, serta komunikasi si korban. Selain itu juga psikolog juga memiliki metode 5B yaitu Berobat 
teratur selalu melakukan kontrol dan cek urine, Berkomunikasi selalu menyampaikan masalaah yang mereka miiliki, Beraktifitas melakukan kegiatan-kegiatan yang yang positif, Berekreasi selalu berolahraga, dan Berdoa. Cara psikolog mengetahui potensi diri dari diri mereka sendiri. Dengan cara psikotest atau tes minat bakat dan melakukan pendataan tentang riwayat hidup si korban.dengan keluarga. Untuk membangun kepercayaan diri korban penyalah gunaan narkoba agar mau diterima kembali dalam lingkungan masyarakat. Dengan caramelihat dan memberitahukan potensi diri yang dia miliki serta sadari akan kelebihannya.

Hambatan-hambatan komunikasi yang dialami psikolog dalam penanganan korban penyaahgunaan narkoba adalah Kesulitan di dalam keluarga , keluarga merupakan faktor penyebab seseorang menggunkan narkoba. Itu dikarenakan tuntutan keluarga kepada si korban sangat besar dan juga seringnya terjadi konflik didalam keluarga. Teman, ini disebabkan karena faktor lingkungan si korban yang juga sebagai pengguna narkoba. Sehingga si korban juga ikut menggunakan narkoba untuk bisa diterima oleh teman-temannya. HP atau Teknologi, semakin maju era teknologi pada saat ini si pengguna sangat mudah untuk mencari tahu tentang semua informasi pembelian dan penjualaan narkoba. Uang, ini dikaarenaan si korban memiliki banyak uang sehingga korban meraasa sangat mudah dan gampang untuk mendapatkaan Narkoba

\section{Saran}

Berdasarkan kesimpulan diatas penulis memiliki saran yaitu :

1. Kepada Rumah Sakit

Agar menambah jamb jenguk keluarga korban yang dapt membantu dalam proses rehabilitasi.

2. Kepada psikolog

Lebih banyak melakukan aktivitas denngan korban. Agar dapat menjalin hubungan yang sangat erat dengan si korban.

3. Keluarga Korban

Untuk tidak mengucilkan dan menuntut banyak kepada korban. Sehingga korban tidak mersa terbebani selama proses

rehabilitasi. 


\section{DAFTAR PUSTAKA}

Asrori,2003. Commuunity Physchology

Budyatna,Muhammad,2011.Teori Komunikasi Antar Pribadi,Kencana,Jakarta

Budyatna,Muhammad,2015.Teori-teori Mengenai Komunikasi Antar Pribadi, Kencana, Jakarta

Hasrullah,2013,Beragam Persepektif Ilmu Komunikasi, PT. Fajar Interpratama Mandiri,Jakarta

http://digilib.uinsby.ac.id/20038/1/Psikologi\%20Komunikasi.pdf

http://e-journal.uajy.ac.id/3241/2/1KOM02733.pdf

Ibrahim Idi Subandy,John Fiske Cultural and Communication Studies Sebuah Pengantar Paling Efektif,Jalasutra, Yogyakarta

J. SEverin, Werner, 2001, Teori Komunikasi Sejarah,Metode,dan Terapan di Dalam Media Massa Edisi Kelima, Kencana,Jakarta

Jazuli, Ahmad ,2007, Upaya Menjaga Diri Dari bahaya Narkoba, PT Bengawan Ilmu, Semarang

Martono,S.K.M, Lidya Harlina, 2006, Pencegahan dan Penanggulangan Penyalahgunaan Narkoba Berbasis Sekolah, PT. balai pustaka (persero), Jakarta

Martono,S.K.M, Lidya Harlina,2008, Membantu Pemulihan Pecandu Narkoba dan Keluarganya Pedoman Bagi Konselor adiksi di masyarakat dan Bagi Setiap Orang yang Peduli dan Terlatih, balai Pustaka, Jakarta

Mulyana,Deddy,2002. Metodologi Penelitian Kualitatif,paradigm baru dlam Ilmu Komunikasi dan Ilmu Sosial Lainnya. Bandung : PT. Remaja Rosdakarya

Rakhmat,1998. Psikologi Komunikasi. Banndung: CV. Remaja Karya

Sugiono,2013, Metodologi Kuantitatif kualitatif, Alfabeta, Jakarta 